\title{
Oncology

\section{Decisions about Cancer Screening - Based on Beliefs or Facts?}

\author{
Corinna Schaefer $^{\mathrm{a}}$ Lothar Weißbach $^{\mathrm{b}}$ \\ a Ärztliches Zentrum für Qualität in der Medizin, Berlin, Germany \\ ${ }^{\mathrm{b}}$ Stiftung Männergesundheit, Berlin, Germany
}

Cancer in its final stage is associated with outstanding pain and suffering. In 2012, 25\% of all deaths in Germany were attributed to cancer [1]. It is estimated that until 2050, cancer incidence will increase by $27 \%$ [2]. Against this background, it becomes clear why the German Minister of Health has declared that 'fighting against cancer' is one of the government's principal goals for the years to come [3], and why powerful institutions like German Cancer Aid promote in their campaigns the slogan 'Against cancer with all our might' [4].

Early detection is assumed to be one of the most efficient instruments to prevent cancer deaths. The rationale for this assumption is that the earlier cancer is diagnosed and treated, the more likely it is that it can be cured. With solid tumors progressing from local to systemic disease, the idea of intervening before progression to a fatal stage, i.e. before the disease becomes systemic, is appealing. And for many tumor entities, observational data has shown that cure rates are significantly higher for early-stage disease, thus confirming the assumption.

On the other hand, clinical decisions should be made by assessing not only the assumed but the proven benefits and harms of the intervention in question. Benefit and harm can best be proven by randomized controlled trials (RCT), the only design allowing for causal associations. However, to date, only a small number of cancer screening interventions have been investigated in RCTs. Observational or non-controlled studies have a high risk of bias, and their findings are limited. Only under the following specific conditions may they be upgraded to a moderate or high evidence level for efficiency [5]: i) there is a large magnitude of effect; ii) all plausible confounding factors would reduce a demonstrated effect or suggest a spurious effect when results show no effect; and iii) there is a dose-response gradient. These criteria do not apply to the observational data on screening tests, except perhaps for cervical cancer screening.

However, when weighing up the available evidence, the main challenge is to determine which endpoints are appropri- ate for assessing the benefits and harms of screening. The WHO 'Principles and Practice of Screening for Disease' by Wilson and Jungner [6] demand that 'the effect of multiple screening needs to be evaluated in terms of reduced morbidity and mortality'. In relation to patient-centered outcome research, which only became important in the last decade, one could add that it also needs to be evaluated in terms of increased quality of life [7].

The existing trials that provide the basis for all screening recommendations show that some screening interventions have the potential to reduce cancer-specific mortality. It is plausible to hypothesize that they also reduce morbidity in those patients whose cancer death is prevented, as these patients most probably will not suffer from late-stage disease burden. The endpoint 'reduction of cancer-specific mortality' is assumed to be appropriate to provide a basis for screening decisions. However, at a closer look, this assumption may be doubted. First, no trial has shown an effect of screening on overall mortality, and neither was any trial powered to show this effect; hence, it remains unknown if screening has the potential to reduce mortality and save lives. Second, all trials provide robust evidence of overdiagnosis, that is, cancers being diagnosed (and treated) that would not have become symptomatic. Overdiagnosis means that otherwise symptomless people are confronted with a cancer diagnosis and burden of disease and undergo unnecessary treatment. From that perspective, screening tests do not reduce but increase morbidity for people receiving an overdiagnosis. Third, the trials show that screened people still die of the cancer the screening test was supposed to find. In these cases, early detection did not prevent cancer death. Due to lead-time bias, these patients are confronted much earlier with a fatal diagnosis. For them, morbidity is also increased, since the time they suffer from disease is prolonged.

Hence, evidence on screening tests seems to be conflicting, showing that benefit and harm both may be considerable and that the most important question 'Does screening save lives?'

\begin{tabular}{ll}
\hline KARGER & (1) 2014 S. Karger GmbH, Freiburg \\
$2296-5270 / 14 / 3715-0004 \$ 39.50 / 0$ \\
Fax +49 7614520714 \\
$\begin{array}{l}\text { Information@Karger.com } \\
\text { www.karger.com }\end{array}$ & $\begin{array}{l}\text { Accessible online at: } \\
\text { www.karger.com/ort }\end{array}$
\end{tabular}


cannot be answered. It is striking that this ambiguity is not reflected in health policies and the public debate. Although the German National Cancer Plan opts for 'informed' decisions, it declares as a principal goal that adherence to screening programs is to be improved [8]. Campaigns are run to encourage people to undergo screening rather than to get informed and make their own decisions on the basis of the best available evidence. Both, physicians and the public have very positive perceptions of cancer screening $[9,10]$. Many women even believe that mammography can prevent breast cancer [10]. One possible explanation may be derived from the Wilson and Jungner criteria for screening tests [6]. Criterion number 7 demands that 'the natural history of the condition, including development from latent to declared disease, should be adequately understood'. In fact, we only have a poor understanding of the natural history of cancer and hardly any data available on untreated cancer, as we presume it is unethical not to offer curative treatment to cancer patients. Our understanding of cancer still goes back to the definition by pathologist Rudolf Virchow 150 years ago, who had made his observations on people dying from cancer and concluded that every disease showing the same pathological patterns would equally lead to death. From this point of view, every treated cancer not resulting in death was a success due to treatment.

Today, we have specific instruments to detect small cancers in asymptomatic people. The phenomenon of overdiagnosis has been acknowledged only recently, and very slowly the perception is arising that not all cancers are lethal if untreated. Currently, it is being discussed that 'cancer' should be redefined [11-13]. Laurence Klotz [11] has offered a new appealing definition: 'Cancer is simply a pathological description of tissue made at a single point of time, rather than a prediction about the natural history of a disease'. Impressive data exists on the natural history of prostate cancer that supports this definition: In a Swedish cohort of men with untreated, localized prostate cancer, only $17 \%$ died of their cancer after a follow-up of 32 years [14]. The idea of a new understanding of cancer is still re- stricted to a small group of scientists without major impact on the public discussion. It would be helpful to promote publicly the idea that not every cancer needs to be found and defeated.

Another explanation for the generally positive attitudes towards cancer screening may lie in certain ethical considerations about our understanding of medicine and cure. We assume that treating patients means intervening actively, and we attribute any sign of recovery to the intervention that has been performed. The medical profession is estimated and admired for saving people's lives by doing something. We think that health is something that can be achieved provided we take the right actions at the right time: the earlier the better. Urologist Peter Albertsen [15] has described more than a decade ago why it is so tempting to believe in the benefit of intervention: 'Physicians are usually quick to recommend treatment for cancer ... If disease progresses, they have done everything possible. If it does not progress, they assume that they have cured the patient. Simply watching a patient is much more difficult. If disease progresses, the physician has failed regardless of whether the tumor was curable. If the disease does not progress, the patient assumes that he did not need physician input.'

The intention behind screening for cancer is to detect it early to treat it early. Our belief in action keeps us from questioning the real benefit of early detection - and from understanding that it may cause harm.

\section{Disclosure Statement}

C. Schaefer is Head of the Department for Knowledge Transfer and Patient Information at the German Agency for Quality in Medicine (AQuMed). AQuMed develops patient versions of evidence-based guidelines for the German Guidelines Program in Oncology. These Guidelines also address cancer screening tests. This paper reflects the author's individual positions, not that of the institution.

Lothar Weißbach is a member of the AOK Expert Committee Prostate 'Cancer'and a member of the Steering Committee 'S3 Guideline Prostate Cancer'.

\section{References}

1 Statistisches Bundesamt: Todesursachenstatistik 2012. www.destatis.de/DE/ZahlenFakten/GesellschaftStaat/Gesundheit/Todesursachen/Tabellen/ EckdatenTU.html;jsessionid $=$ B754B03A5F3A8F2 A560094D5DA534F08.cae3.

2 Beske F: Sechs Entwicklungslinien in Gesundheit und Pflege. Analyse und Lösungsansätze. Kiel, 2011. www.dggpp.de/dggpp2011/beske/Band-119. $p d f$.

3 Gröhe H: «Die Bekämpfung von Krebs ist ein wichtiges Anliegen dieser Regierung». Cited from: www.bmg.bund.del.

4 «Mit aller Kraft gegen den Krebs». Kampagne der Deutsche Krebshilfe. Cited from: www.mit-allerkraft.de/ueber-die-kampagne.html.

$\checkmark 5$ The GRADE Working Group: Grading quality of evidence and strength of recommendations. BMJ 2004;328:1490-1494.
6 Wilson JMG, Jungner G: Principles and practice of screening for diseases (1968). Geneva, World Health Organization, 1968. whqlibdoc.who.int/ php/WHO_PHP_34.pdf.

7 SGB V § 35b. dejure.org/gesetze/SGB_V/35b.html.

8 www.bmg.bund.de/praevention/nationaler-krebsplan/ was-haben-wir-bisher-erreicht/ziel-1-inanspruchnahme-krebsfrueherkennung.html.

9 Wegwarth O, Schwartz LM, Woloshin S, Gaissmaier W, Gigerenzer G: Do physicians understand cancer screening statistics? A national survey of primary care physicians in the United States. Ann Intern Med 2012;156:340-349.

10 Klusendieck M, Diener J: Inanspruchnahme des qualitätsgesicherten Mammographie-Screenings Follow-Up-Studie 2012.www.bmg.bund.de/fileadmin/ dateien/Publikationen/Forschungsberichte/2012/ 2012_4/Abschlussbericht_Mammographie-Screening_ Follow-Up_Studie_2012.pdf.
Klotz L: Cancer overdiagnosis and overtreatment Curr Opin Urol 2012;22:203-209.

12 Esserman LJ, Thompson IM Jr, Reid B: Overdiagnosis and overtreatment in cancer: an opportunity for improvement. JAMA 2013;310:797-798.

13 Carter HB, Partin AW, Walsh PC, Trock BJ, Veltri RW, Nelson WG, Coffey DS, Singer EA, Epstein JI: Gleason score 6 adenocarcinoma: should it be labeled as cancer? J Clin Oncol 2012;30:4294-4296.

14 Popiolek M, Rider JR, Andrén O, Andersson SO, Holmberg L, Adami HO, Johansson JE: Natural history of early, localized prostate cancer: a final report from three decades of follow-up. Eur Urol 2013;63:428-435.

15 Albertsen P: Editorial comment. J Urol 2000;164: 1867-1870. 